\title{
SISTEM INFORMASI GEOGRAFIS PENDATAAN DAN MONITORING REKLAME BERBASIS ANDROID
}

\author{
Muhammad Venza Utama ${ }^{1}$, Rina Noviana ${ }^{2}$ \\ Program Pascasarjana Universitas Gunadarma ${ }^{1,2}$ \\ Jalan Margonda Raya No.100 Depok \\ Sur-el : mvenzaa@gmail.com *1
}

\begin{abstract}
This study aims to (1) create an Android-based geographic information system to make it easier for field officers of the Regional Revenue Agency to collect billboards and monitor the status of billboard permits installed in their area, (2) to make designs that are attractive and easy to use by users. This study uses the waterfall method which consists of 5 stages, namely planning, design, implementation, testing, operation and maintenance. The result of this study is a geographic information system for data collection and monitoring of advertisements based on Android which was developed specifically for the implementation of data collection and monitoring of advertisements. System testing is done by the Black-Box, the test results, the participants stated that the functional aspects of the application had met the specifications required by the user. Tests were also carried out with involving 5 Android smartphones with different specifications. The results of this test are that the display of the billboard data collection and monitoring application is different on each smartphone, the difference in the display is in the level of color brightness. There are also differences in terms of the performance of applications that run on this type of smartphone with the Android version which is quite old. The areas studied and became the test locations were the municipality of East Jakarta and the province of Lampung.
\end{abstract}

Keywords: android, information system, advertisement

\begin{abstract}
Abstrak : Penelitian ini bertujuan untuk (1) membuat sistem informasi geografis berbasis Android untuk memudahkan petugas lapangan Badan Pendapatan Daerah melakukan pendataan reklame dan monitoring status izin reklame yang terpasang didaerahnya, (2) membuat rancangan yang menarik dan mudah dipakai oleh pengguna. Tahapan penelitian ini menggunakan metode waterfall yang terdiri dari 5 taha.p yaitu perencanaan, perancangan, implementasi, pengujian, operasi dan pemeliharaan. Hasil dari penelitian ini adalah sistem informasi geografis pendataan dan monitoring reklame berbasis Android yang dikembangkan khusus untuk pelaksanaan pendataan dan monitoring reklame. Pengujian sistem dilakukan dengan metode Black-Box Testing menghasilkan para peserta menyatakan bahwa aspek fungsional aplikasi sudah memenuhi spesifikasi kebutuhan pengguna. Pengujian juga dilakukan dengan melibatkan 5 buah smartphone Android dengan spesifikasi berbeda-beda. Hasil pengujian ini yaitu tampilan aplikasi pendataan dan monitoring reklame ini berbeda pada tiap smartphone, perbedaan tampilan terdapat pada tingkat kecerahan warna. Terdapat juga perbedaan dari sisi performa aplikasi yang berjalan pada jenis smartphone dengan versi Android yang sudah cukup berumur. Daerah yang diteliti dan menjadi lokasi pengujian yaitu Kotamadya Jakarta Timur dan Provinsi Lampung
\end{abstract}

Kata kunci: android, sistem informasi, pendataan reklame

\section{PENDAHULUAN}

Pendataan reklame adalah salah satu kegiatan yang dilaksanakan dalam rangka mengoptimalkan pencapaian target pendapatan pajak daerah. Kegiatan ini dilakukan dengan menerjunkan tim petugas pendataan reklame dari
Badan Pendapatan Daerah (Bapenda) dan staf koordinator dari kecamatan-kecamatan dengan menyusuri sejumlah jalan protokol dengan mencatat reklame yang terpasang dan melakukan pengambilan gambar/foto reklame yang terpasang. Jika dari pengecekan tersebut, ditemukan reklame yang terpasang tidak berizin, 
atau terdapat reklame yang sudah habis masa berlakunya tetapi belum melakukan perpanjangan izin pemasangan reklame, maka Badan Pendapatan Daerah segera mengirim surat tagihan terhadap pelaku usaha reklame sebagai wajib pajak reklame tersebut. Jika wajib pajak reklame belum melakukan kewajiban atas pembayaran reklame, maka reklame yang terpasang di jalan tersebut akan dilepas oleh petugas.

Sebagian daerah di Indonesia masih melakukan proses pendataan reklame tersebut secara manual menggunakan formulir kertas, dimulai saat petugas melakukan pengecekan di lapangan kemudian berlanjut pemberkasan dan laporan reklame yang telah dilakukan pengecekan, hingga surat menyurat kepada pelaku usaha dalam hal ini wajib pajak reklame.

Masalah yang muncul dari proses manual tersebut diantaranya petugas di lapangan membutuhkan waktu lebih banyak dalam melakukan pendataan reklame disebabkan petugas harus melakukan pengecekan papan reklame yang terpasang satu persatu, hal tersebut dapat membuat Badan Pendapatan Daerah terlambat mengetahui status izin reklame yang terpasang didaerahnya, sehingga turut berdampak pada keterlambatan wajib pajak dalam melaksanakan kewajibannya untuk pembayaran pajak papan reklame. [1], Potensi pajak reklame belum tergali secara optimal, padahal apabila potensi ini dapat dimaksimalkan maka akan menambah kontribusi terhadap PAD Kota. [2], Kurangnya kesadaran pelaku usaha atau pemilik papan reklame, mereka tidak mementingkan keindahan Kota, pelaku usaha hanya memikirkan produk-produk mereka supaya cepat diketahui orang-orang.

Seiring dengan perkembangan teknologi informasi, kegiatan pendataan reklame dapat memanfaatkan SIG yang memiliki kemampuan untuk pemantauan secara real time dan akurat lokasi papan reklame yang tidak berizin maupun sudah habis masa berlakunya. Sistem Informasi Geografis dapat diakses secara langsung kapanpun dan dimanapun sehingga meminimalisir kendala tempat dan waktu. Sehingga Bapenda maupun wajib pajak reklame dapat mengetahui dan mengawasi reklame yang sudah memasuki masa jatuh tempo maupun yang belum memasuki jatuh tempo pajak reklame.

Sistem informasi geografis (SIG) merupakan sistem informasi berbasis computer yang digunakan untuk mengolah dan menyimpan data atau informasi berbasis geografis [3].SIG merupakan aplikasi yang dikembangkan untuk memecahkan persoalan yang berkaitan dengan permukaan bumi, pemanfaatan SIG dalam pengembangan berpikir spasial menunjukkan adanya kontribusi positif SIG dalam mengembangkan kemampuan berpikir spasial. GIS telah banyak dimanfaatkan dalam berbagai bidang [4]. Memanfaatkan sistem informasi dalam aplikasi pelaporan pelacakan kejahatan [5]. Memanfaatkan aplikasi GIS dalam pemetaan batas administrasi, tanah, geologi penggunaan lahan dan lereng [6]. Memanfaatkan SIG untuk analisa spasial potensi lembaga pendidikan keterampilan [7]. Menerapkan GIS berbasis WEB untuk pengembangan wisata di kabupaten Langkat [8]. Mengimplementasikan SIG dalam pemetaan asal mahasiswa[9]. SIG memberikan 
informasi mengenai pelayanan kesehatan kapanpun dan dimanapun [10].

\section{METODOLOGI PENELITIAN}

Penelitian ini menggunakan model pengembangan waterfall yang merupakan bagian dari metodologi SDLC (Software Development Life Cycle). Model waterfall memiliki beberapa tahapan prosedur meliputi perencanaan, analisis, perancangan, implementasi, integrasi dan pengujian, sampai dengan operasi dan pemeliharaan.

Obyek dalam penelitian ini adalah pelaksanaan pendataan reklame di lapangan yang dilakukan oleh petugas dari perusahaan penyedia jasa tenaga outsourcing untuk Bapenda terkait dengan penarikan data pajak reklame berdasarkan posisi lokasi reklame dan status izin reklame termasuk datadata pendukung untuk keperluan monitoring wajib pajak oleh Bapenda. Daerah yang di teliti dan menjadi lokasi pengujian SIG yaitu Kotamadya Jakarta Timur dan Provinsi Lampung.

\subsection{Tahap Perencanaan}

Perencanaan merupakan langkah awal yang dilakukan dalam penelitian ini. Langkah ini bertujuan untuk mengetahui masalah yang terjadi berkaitan dengan pelaksanaan pendataan dan monitoring reklame di lapangan oleh petugas dari perusahaan penyedia tenaga outsourcing, serta menyampaikan solusi berupa pemanfaatan teknologi informasi untuk mengatasi masalah yang terjadi.

Flowmap manual yang sedang berjalan yang dilakukan oleh petugas lapangan Bapenda.

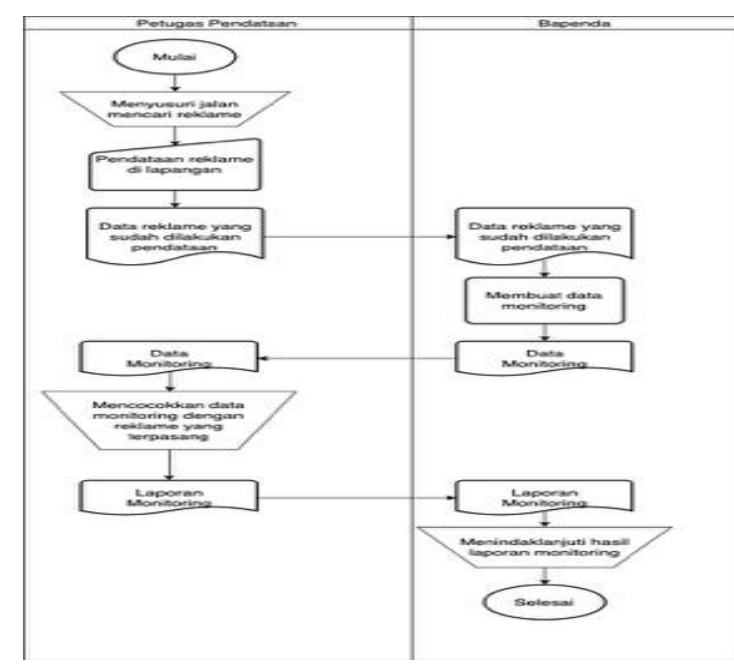

Gambar 1. Flowmap Manual

Perencanaan sistem merupakan penguraian dari suatu sistem yang utuh ke dalam bagian-bagian komponennya untuk mengidentifikasi dan mengevaluasi permasalahan. Penelitian ini memberikan usulan berupa flowmap untuk menyampaikan solusi berupa pemanfaatan teknologi informasi dalam mengatasi masalah yang terjadi sebagai bagian dari perencanaan sistem.

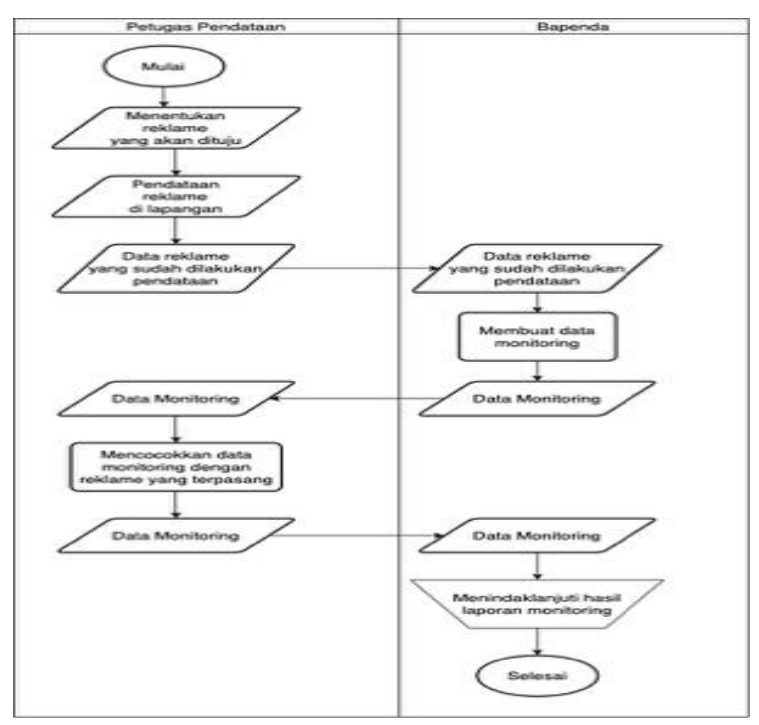

Gambar 2. Flowmap Usulan

\subsection{Tahap Analisis}

Tahap analisis dilakukan bertujuan untuk menguraikan masalah yang berkaitan dengan 
pelaksanaan pendataan dan monitoring reklame di lapangan oleh petugas dari perusahaan penyedia tenaga outsourcing, serta mengumpulkan berbagai informasi yang berkaitan dengan pelaksanaan pendataan dan monitoring reklame di lapangan, fasilitas-fasilitas pendukung yang bisa digunakan dalam pelaksanaan penelitian.

Tahapan analisis yang pertama yaitu analisis kebutuhan fungsional. Kebutuhan yang perlu diketahui diantaranya kondisi atau kemampuan yang dibutuhkan pengguna SIG dalam menyelesaikan suatu persoalan atau mencapai tujuan. Kondisi atau kemampuan yang harus dimiliki oleh SIG dalam memenuhi standar operasional prosedur pendataan dan monitoring reklame. Analisis kebutuhan fungsional merupakan penjelasan proses fungsi berupa penjelasan secara terinci setiap fungsi yang digunakan untuk menyelesaikan masalah.

Analisis kebutuhan non fungsional dilakukan guna mengetahui perangkat-perangkat yang diperlukan dalam mengembangkan SIG pendataan dan monitoring reklame berbasis Android. Perangkat pendukung yang dibutuhkan terdiri atas perangkat keras (hardware) dan perangkat lunak (software). Kebutuhan terhadap hardware dan software yang digunakan mengacu pada kemampuan perangkat tersebut dalam mengoperasikan SIG pendataan dan monitoring reklame secara online, serta mampu menjalankan fitur-fitur yang terdapat dalam SIG pendataan dan monitoring reklame berbasis Android. Oleh sebab itu diperlukan hardware yang memadai dari segi performance dan daya tampung penyimpanan data.
Data primer yang digunakan dalam penelitian ini didapat langsung dari perusahaan penyedia jasa tenaga outsourcing untuk Bapenda. Adapun data yang dikumpulkan berupa daftar jenis reklame, daftar jenis ruang, daftar fungsi jalan, daftar kecamatan, daftar kelurahan, daftar nama petugas, data monitoring reklame, serta daftar status reklame. Data yang dikumpulkan seluruhnya bersumber dari pihak perusahaan penyedia tenaga outsourcing untuk Bapenda. Data-data tersebut digunakan sebagai dasar untuk mendesain SIG pendataan dan monitoring reklame berbasis Android.

\subsection{Tahap Perancangan}

Pada tahap ini, dilakukan penerjemahan kebutuhan menjadi sebuah perancangan perangkat lunak yang dapat diperkirakan sebelum dilakukan proses penulisan kode program. Tahap ini berfokus pada struktur data, arsitektur perangkat lunak, representasi tampilan antarmuka, dan detail algoritma prosedural.

Dalam rancangan sistem ini, terdapat dua aktor yang saling berinteraksi yaitu Petugas Lapangan dan Bapenda. Untuk mengetahui secara keseluruhan fungsi beserta aktor-aktor yang bertanggungjawab pada setiap fungsi dari elemen sistem yang dirancang dapat dilihat pada Gambar 4 berikut : 


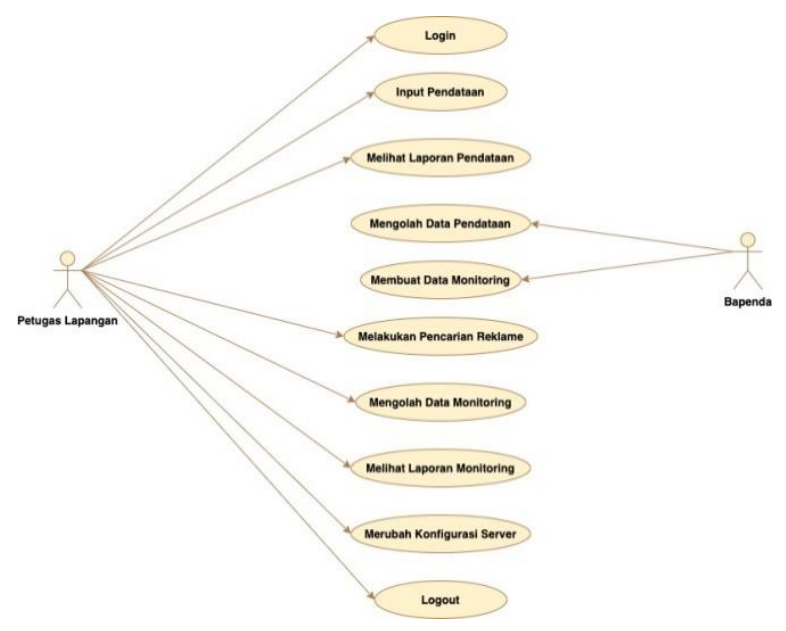

Gambar 3. Use Case Diagram

Perancangan storyboard pada SIG pendataan dan monitoring reklame berbasis Android meliputi: (1) Halaman login; (2) Halaman beranda; (3) Halaman pendataan; (4) Input pendataan; (5) Pendataan terkirim; (6) Halaman monitoring; (7) Menu laporan; (8) Laporan pendataan; (9) Laporan monitoring; (10) Halaman pengaturan. Hasil dari perancangan storyboard menjadi acuan dalam proses pengembangan SIG pendataan dan monitoring reklame berbasis Android.

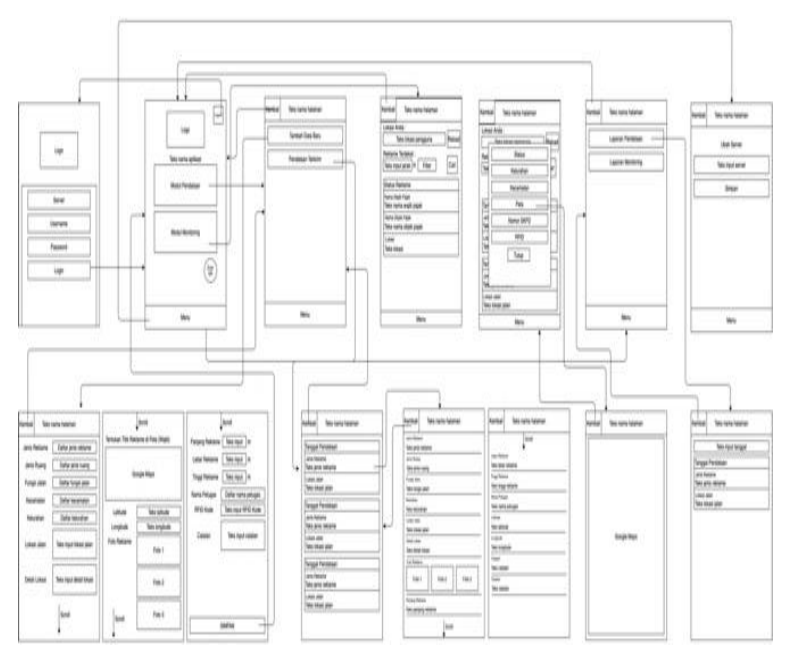

Gambar 4. Storyboard

Tahapan perancangan basis data dilakukan sesuai dengan hasil analisis kebutuhan pengguna yang telah di identifikasi pada perusahaan jasa penyedia tenaga outsourcing untuk Bapenda. tahapan dalam perancangan basis data di bagi menjadi 3 tahap utama diantaranya

- Perancangan basis data konseptual

- Perancangan basis data logikal

- Perancangan basis data fisikal

SIG pendataan dan monitoring reklame berbasis Android ini menggunakan basis data yang diberi nama "pendataanreklame.realm". Dalam basis data ini terdapat empat buah tabel yaitu tabel Profile, PostPendataan, PostMonitoring, dan RFIDMonitoring, disertai perancangan Class Diagram.

Tabel 1. Struktur Tabel Profile

\begin{tabular}{ccc}
\hline Field & Type & Keterangan \\
\hline id_profile & Integer & Primary Key \\
username & String & Username pengguna \\
password & String & Password pengguna \\
url & String & Url server untuk akses \\
& & aplikasi \\
\hline
\end{tabular}

\section{Tabel 2. Struktur Tabel PostMonitoring}

\begin{tabular}{lll}
\hline Field & Type & Keterangan \\
\hline id_monitoring & Integer & Primary Key \\
postKode & String & Kode pendataan \\
wpName & String & Nama wajib pajak \\
postRoadLocation & String & Nama lokasi jalan \\
status & String & Status reklame \\
\hline
\end{tabular}

Tabel 3. Struktur Tabel RFIDMonitoring

\begin{tabular}{lll}
\hline Field & Type & Keterangan \\
\hline id_rfidmonitoring & Integer & Primary Key \\
status_ & String & Status reklame \\
lokasi_- & String & Lokasi reklame \\
wp__ $_{\text {opName_ }}$ & String & Nama wajib pajak \\
rfidCode_ & String & Nama objek pajak \\
& String & Kode RFID \\
kode_ & reklame \\
\hline
\end{tabular}


Tabel 4. Struktur Tabel PostPendataan

\begin{tabular}{|c|c|c|}
\hline Field & Type & Keterangan \\
\hline id_pendataan & Integer & Primary Key \\
\hline date & String & $\begin{array}{l}\text { Tanggal } \\
\text { pendataan }\end{array}$ \\
\hline postKode & String & $\begin{array}{l}\text { Kode } \\
\text { pendataan }\end{array}$ \\
\hline postJenisReklameId & Integer & $\begin{array}{l}\text { Id jenis } \\
\text { reklame } \\
\text { pendataan }\end{array}$ \\
\hline postJenisReklameName & String & $\begin{array}{l}\text { Nama jenis } \\
\text { reklame } \\
\text { pendataan }\end{array}$ \\
\hline postFungsiRuangId & Integer & $\begin{array}{l}\text { Id fungsi ruang } \\
\text { pendataan }\end{array}$ \\
\hline postFungsiRuangName & String & $\begin{array}{l}\text { Nama fungsi } \\
\text { ruang } \\
\text { pendataan }\end{array}$ \\
\hline postFungsiJalanId & Integer & $\begin{array}{l}\text { Id fungsi jalan } \\
\text { pendataan }\end{array}$ \\
\hline postFungsiJalanName & String & $\begin{array}{l}\text { Nama fungsi } \\
\text { jalan } \\
\text { pendataan }\end{array}$ \\
\hline postRoadLocation & String & $\begin{array}{l}\text { Lokasi jalan } \\
\text { pendataan }\end{array}$ \\
\hline postDetailLocation & String & $\begin{array}{l}\text { Detail lokasi } \\
\text { pendataan }\end{array}$ \\
\hline image1 & String & $\begin{array}{l}\text { Foto } 1 \text { reklame } \\
\text { pendataan }\end{array}$ \\
\hline image2 & String & $\begin{array}{l}\text { Foto } 2 \text { reklame } \\
\text { pendataan }\end{array}$ \\
\hline image 3 & String & $\begin{array}{l}\text { Foto } 3 \text { reklame } \\
\text { pendataan }\end{array}$ \\
\hline postKelurahanId & Integer & $\begin{array}{l}\text { Id kelurahan } \\
\text { pendataan }\end{array}$ \\
\hline postKelurahanName & String & $\begin{array}{l}\text { Nama } \\
\text { kelurahan } \\
\text { pendataan }\end{array}$ \\
\hline postPetugasId & Integer & $\begin{array}{l}\text { Id petugas } \\
\text { pendataan }\end{array}$ \\
\hline postPetugasName & String & $\begin{array}{l}\text { Nama petugas } \\
\text { pendataan }\end{array}$ \\
\hline latitude & String & $\begin{array}{l}\text { Titik latitude } \\
\text { pendataan }\end{array}$ \\
\hline longitude & String & $\begin{array}{l}\text { Titik longitude } \\
\text { pendataan }\end{array}$ \\
\hline postNotes & String & $\begin{array}{l}\text { Catatan } \\
\text { pendataan }\end{array}$ \\
\hline postLebar & String & $\begin{array}{l}\text { Lebar reklame } \\
\text { pendataan }\end{array}$ \\
\hline postTinggi & String & $\begin{array}{l}\text { Tinggi reklame } \\
\text { pendataan }\end{array}$ \\
\hline
\end{tabular}

Selanjutnya diagram kelas atau class diagram menggambarkan struktur sistem dari segi pendefinisian kelas-kelas yang akan dibuat untuk membangun sistem.

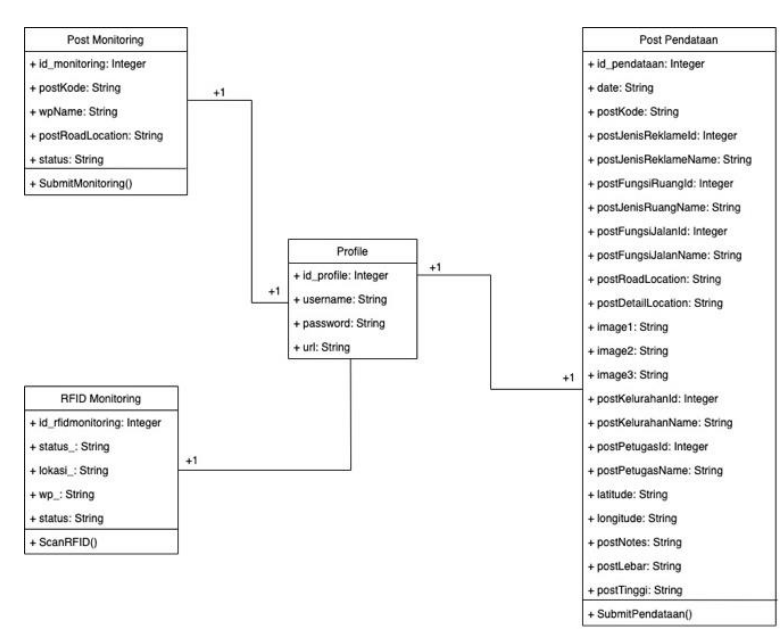

Gambar 5. Class Diagram

\subsection{Tahap Implementasi}

Pada tahap ini, perancangan sistem direalisasikan menjadi serangkaian program atau unit program menggunakan IDE (Integrated Development Environment) yang memiliki beberapa fasilitas yang diperlukan dalam pembangunan perangkat lunak. IDE yang digunakan dalam pengembangan SIG pendataan dan monitoring reklame berbasis Android adalah Android Studio.

Pada tahap ini dilakukan penulisan kode program untuk membangun sistem dengan menggunakan konsep pemrograman berorientasi objek. Bahasa pemrograman berorientasi objek yang digunakan dalam penelitian ini yaitu Java dan XML.

Langkah ini dilakukan berdasarkan saran dari para ahli atau pakar terhadap produk yang telah dikembangkan. Jika ditemukan ketidaksesuaian dengan spesifikasi yang telah ditetapkan, maka produk akan dilakukan perbaikan. Jika produk telah sesuai dengan bisnis 
proses yang disepakati maka langsung dilanjutkan pada tahap berikutnya yaitu tahap pengujian.

\subsection{Tahap Pengujian}

Pada tahap ini, unit program di uji sebagai sebuah sistem yang utuh untuk menjamin bahwa kompetensi sistem telah seluruhnya dipenuhi. Pengujian dilakukan secara terbatas dengan menyertakan subyek penelitian yaitu para quality assurance (QA) dari perusahaan penyedia tenaga outsourcing untuk Bapenda, dimana subyek penelitian diberi kesempatan untuk menjalankan secara full life cycle SIG pendataan dan monitoring reklame berbasis Android yang dikembangkan. Jumlah subyek penelitian sebanyak 5 orang.

Pada tahap ini juga dilakukan pengujian yang melibatkan pengguna akhir atau end user secara terbatas dari produk SIG pendataan dan monitoring reklame berbasis Android menggunakan metode Black-box Testing sebelum produk dirilis untuk digunakan oleh end user secara umum.

\subsection{Tahap Operasi dan Pemeliharaan}

Setelah melalui serangkaian tahap-tahap pengembangan, produk akhir dari penelitian ini berupa sistem informasi geografis pendataan dan monitoring reklame berbasis Android yang dapat memberikan kemudahan dalam pelaksanaan pendataan reklame secara real time dan akurat di lapangan serta mempermudah pengguna dalam memperoleh informasi untuk monitoring pajak reklame. Pada tahap ini juga dilakukan pemeliharaan untuk mempertahankan sistem tetap berjalan dengan baik dan minim kesalahan jika di masa yang akan datang perlu digunakan secara massal.

\subsection{Teknik Pengolahan Data Penyusunan SIG}

Peta dasar yang digunakan adalah peta digital yang dikeluarkan oleh Google Cloud Platform. Kemudian layanan yang digunakan adalah Google Maps API. Proses penyusunan SIG terdiri dari:

- Mendaftarkan identitas proyek di laman Google Cloud Platform Console.

- Memilih layanan yang akan digunakan yaitu Google Maps API.

- Membuat API Key untuk integrasi proyek dengan Google Maps API.

- Sinkronisasi library Google Maps API ke dalam proyek.

- Mengolah tampilan antarmuka untuk memuat Google Maps.

- Mengolah modul untuk mengoperasikan Google Maps di dalam proyek.

- Mengolah data monitoring yang di dapat dari web server melalui jalur komunikasi REST API, data berupa titik koordinat latitude dan longitude lokasi reklame.

- Inisialisasi titik koordinat lokasi reklame menjadi object dalam elemen Array.

- Menerapkan Array di dalam modul yang terintegrasi dengan Google Maps.

- Menerapkan fungsi deklarasi object elemen Array untuk menjadi titik poin lokasi di dalam modul yang terintegrasi dengan Google Maps menggunakan format Marker.

- Pada akhir pekerjaan, sistem dapat menampilkan titik lokasi reklame di dalam modul yang 
terintegrasi dengan Google Maps secara real time dan akurat.

\section{HASIL DAN PEMBAHASAN}

Hasil penelitian sistem informasi yang di beri nama SIG pendataan dan monitoring reklame berbasis Android ini dikembangkan khusus untuk Badan Pendapatan Daerah, yang berkaitan dengan pelaksanaan penarikan data pajak reklame, dimana data transaksi untuk pajak reklame akan di entri dalam aplikasi dan otomatis akan menghitung nilai pajak reklame berdasarkan lokasi reklame dan ukuran reklame serta support sampai mencetak SKPD.

\subsection{Pembuatan Layout}

Layout digunakan untuk mengimplementasikan setiap fungsi sistem yang telah dirancang. Layout dalam pembuatan sistem informasi berbasis Android menggunakan bahasa pemrograman XML. Setiap layout memiliki konfigurasi kode pemrograman yang berbeda sesuai dengan fungsi dan kebutuhannya. Berikut potongan kode XML dari salah satu layout.

$<$ ?xml version="1.0" encoding="utf$8 " ?>$

$<$ Relativelayout

d.com/apk/res/android"

xmlns:app="http://schemas.android.co

$\mathrm{m} / \mathrm{apk} / \mathrm{res}$-auto"

xmlns:tools="http: / / schemas . android. com/tools"

android:layout_width="match_parent"

android: layout_height="match_parent"

android: background="@color/brokenWhi

te"

tools: context=". MainActivity">

android:id="e+id/imageBillboard"

android: layout width="150dp"

android: layout_height="75dp" xmlns:android="http://schemas.androi

$<$ ImageView

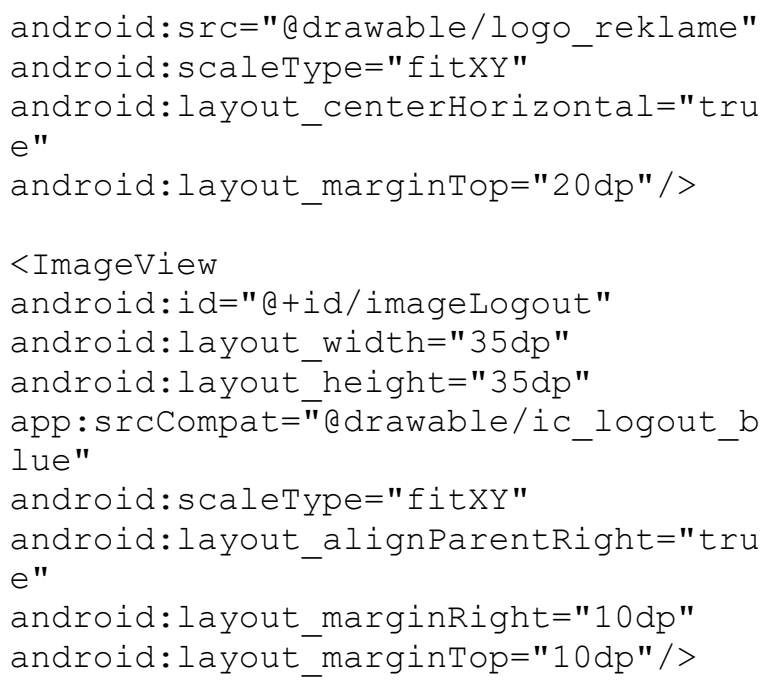

\subsection{Pembuatan Logika Program}

Pengembangan sistem informasi berbasis Android native menggunakan konsep pemrograman berorientasi objek yaitu Java sebagai logika programnya. Setiap layout yang telah dibuat, dikendalikan fungsionalitasnya menggunakan logika program Java menjadi layout statis ataupun dinamis. Setiap layout memiliki logika program yang berbeda-beda sesuai aktifitas atau fungsi yang dibutuhkan pada setiap layout-nya. Berikut potongan kode dari salah satu logika program yang telah dibuat.

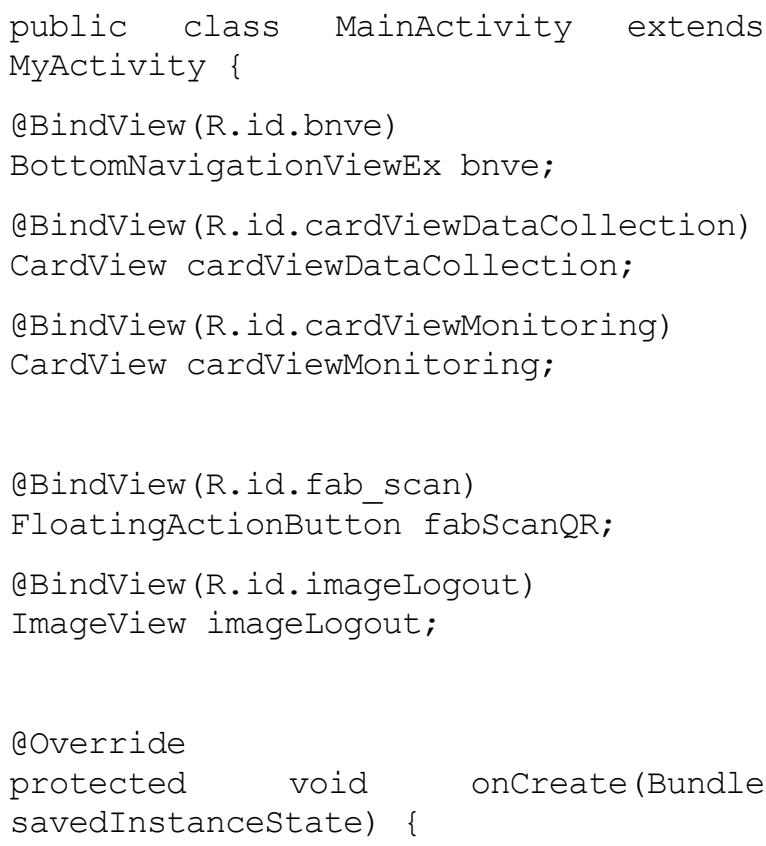




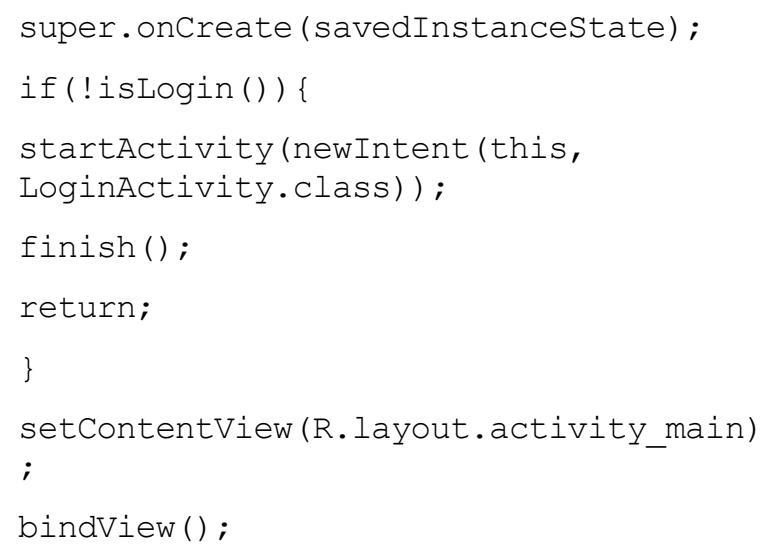

\subsection{Pembuatan Basis Data}

Pada tahap ini Class Diagram atau diagram kelas yang telah dirancang sebelumnya di implementasi menjadi basis data yang sesungguhnya. Proses implementasi yang dilakukan yaitu dengan menggunakan basis data Realm Database yang menganut konsep NoSQL. Basis data NoSQL menggunakan model data untuk mengakses dan mengelola data.

Adapun dalam penelitian ini cara pembuatan tabel dalam basis data dengan konsep NoSQL dilakukan dengan tahapan awal yaitu membuat file
Java untuk model data. Berikut potongan kode dari salah satu file Java model data.

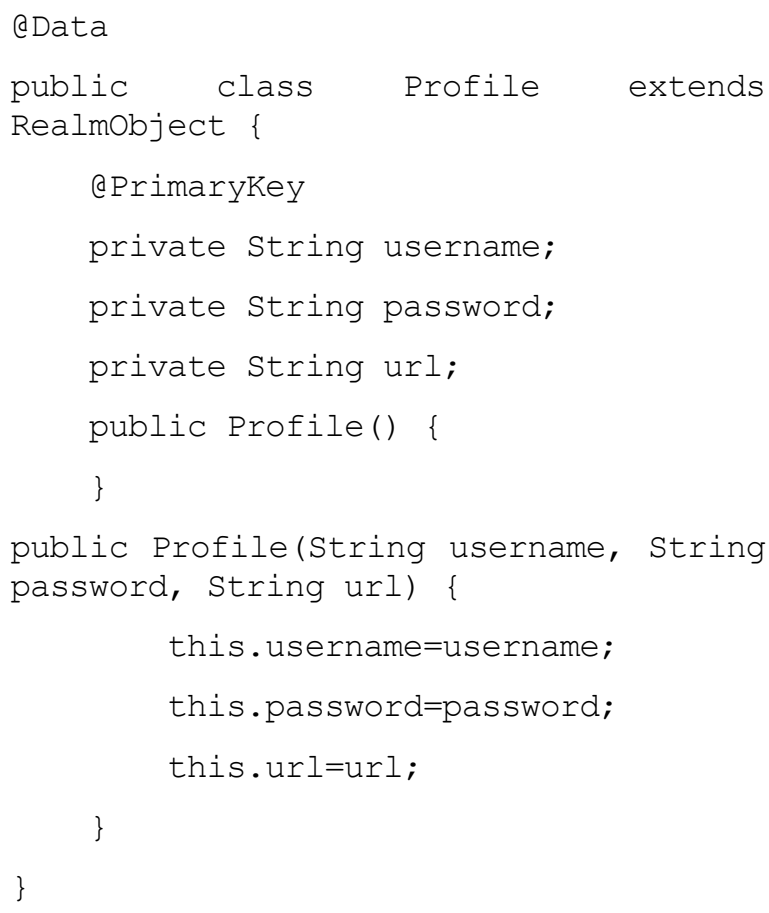

Untuk penggunaan basis data, aplikasi SIG pendataan dan monitoring reklame berbasis Android melakukan akses langsung pada file-file Java sesuai dengan kebutuhan, sebagai contoh saat menu monitoring mengakses data dari server, maka aplikasi memerlukan username dan password pengguna atau otorisasi untuk dapat mengakses server, otorisasi tersebut tersimpan dalam objek basis data file Profile.java. Maka perlu dilakukan pemanggilan objek tersebut di dalam fungsi menu monitoring. Berikut potongan kode salah satu contoh penggunaan Realm Database.

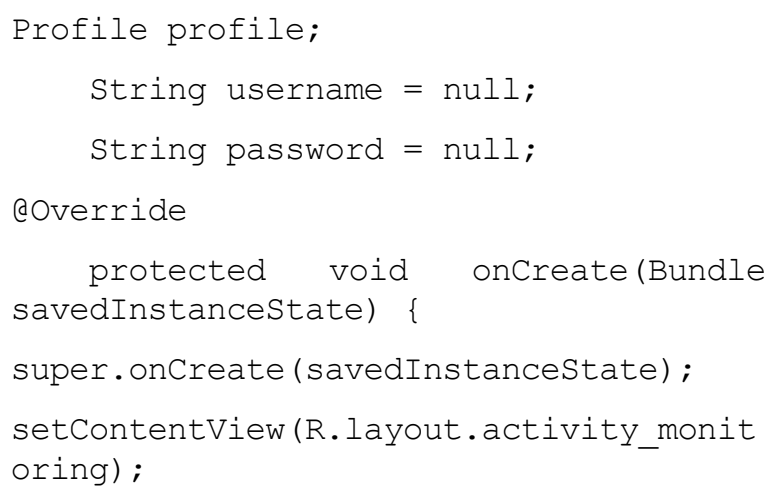




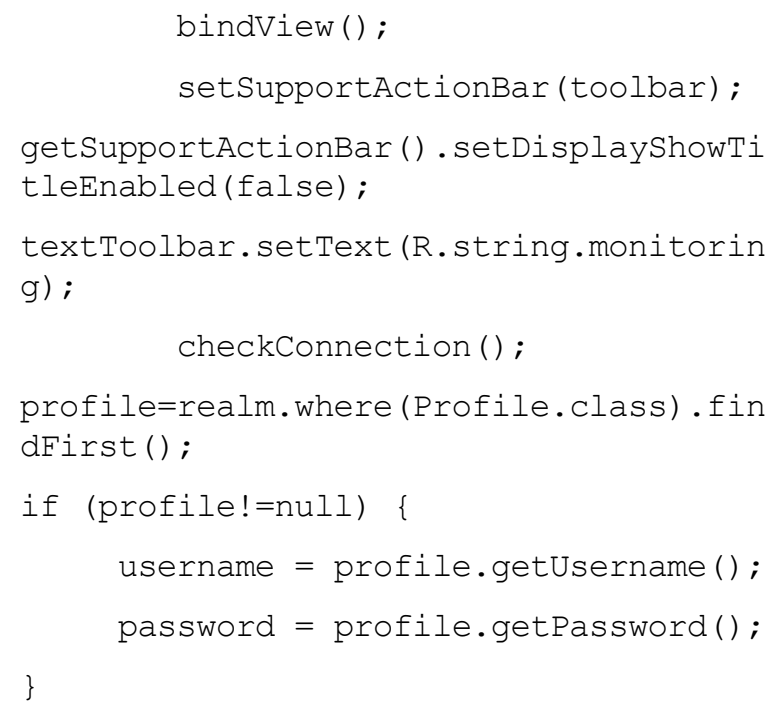

\subsection{Penyusunan Sistem Informasi Geografis}

Dalam penyusunan SIG pada aplikasi, perlu dilakukan pembuatan layout antarmuka menggunakan pemrograman XML untuk menempatkan Google Maps di halaman aplikasi.

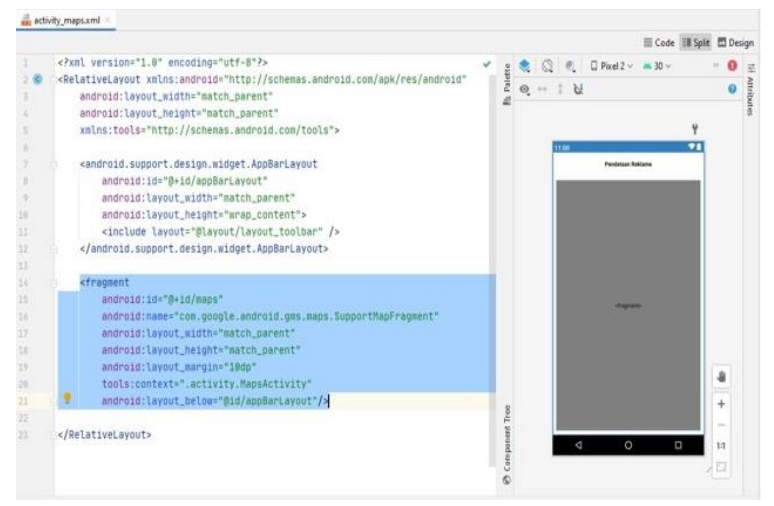

\section{Gambar 7. Pembuatan layout peta Google Maps}

Selanjutnya pembuatan logika program menggunakan file Java untuk menjalankan fungsionalitas Google Maps pada layout yang telah dibuat, dengan cara deklarasi komponen SupportMapFragment dari Google Maps library menjadi objek bernama mMap. Objek mMap tersebut merupakan objek yang menjalankan fungsi dari Google Maps itu sendiri.

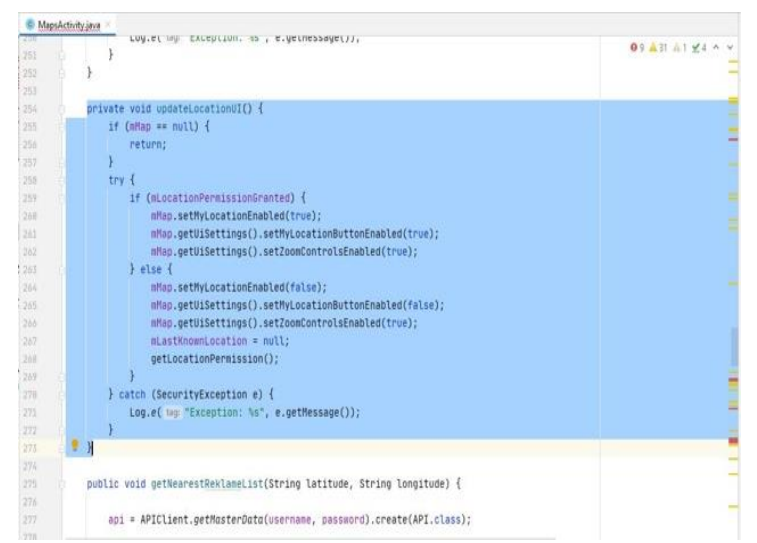

\section{Gambar 8. Logika program Google Maps}

Hasil dari pembuatan layout dan pembuatan logika program untuk menanamkan Google Maps pada aplikasi SIG pendataan dan monitoring reklame berbasis Android yaitu sebuah fitur SIG yang berguna untuk mengetahui posisi reklame di dalam aplikasi secara real-time karena data yang digunakan diakses langsung dari server. Halaman fitur SIG pada aplikasi SIG pendataan dan monitoring reklame berbasis Android, posisi reklame yang terpasang diberi tanda marker berwarna hijau.

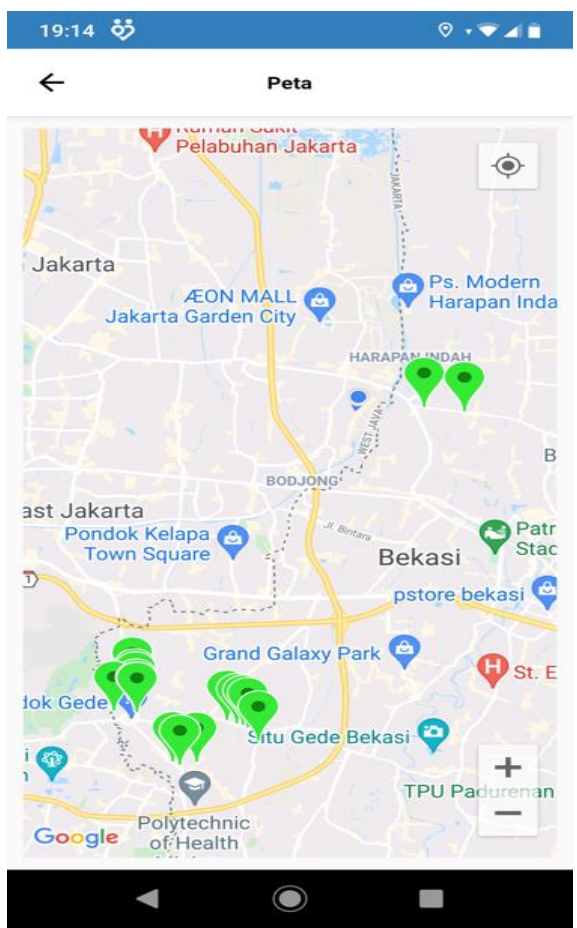

Gambar 9. Halaman Fitur SIG 


\subsection{Hasil Pembuatan Antarmuka}

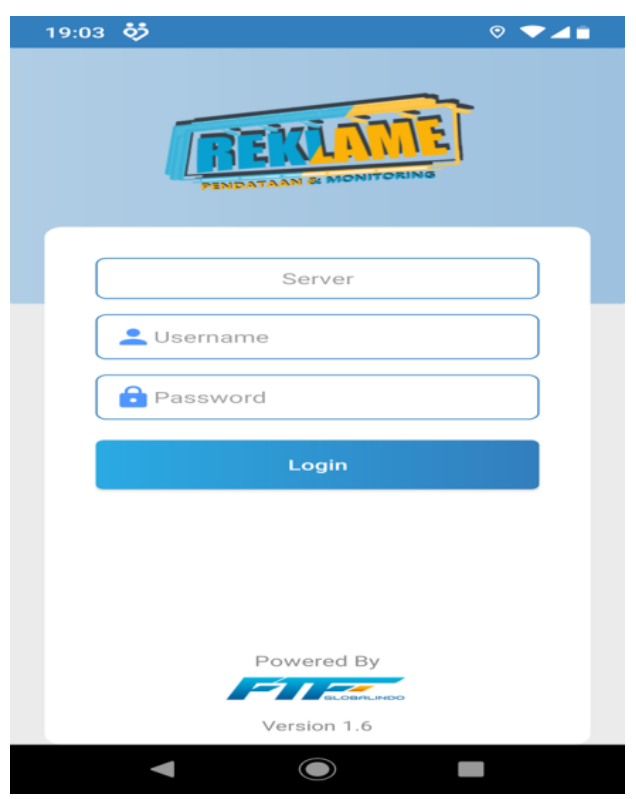

Gambar 10. Halaman Login

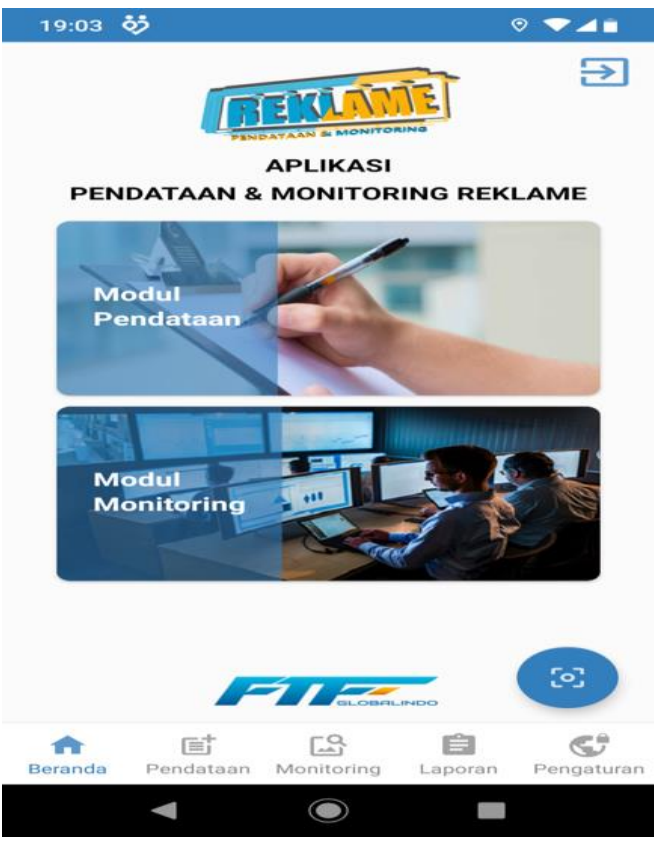

Gambar 11. Halaman Beranda

\section{KESIMPULAN}

Dari uraian dan proses pembuatan aplikasi Sistem Informasi Geografis ini, dapat diperoleh kesimpulan sebagai berikut.
1. Penelitian ini menghasilkan sebuah sistem informasi geogragfis berbasis Android bernama Aplikasi Pendataan dan Monitoring Reklame yang memiliki tampilan antarmuka menarik serta mudah digunakan.

2. Aplikasi memiliki fitur SIG menggunakan Google Maps yang dapat mempermudah pelaksanaan pendataan dan monitoring reklame di lapangan oleh petugas outsourcing untuk Badan Pendapatan Daerah dalam rangka menunjang kinerja dan kualitas pelayanan menjadi lebih efisien serta akurat dalam mengetahui dan menyajikan informasi terkait status izin maupun lokasi papan reklame yang terpasang.

3. Hasil dari pengujian metode Black-Box Testing yang melibatkan lima peserta dari perusahaan penyedia tenaga outsourcing untuk menguji sistem dari aspek spesifikasi fungsional tersebut para peserta menyatakan bahwa aspek fungsional aplikasi sudah sesuai harapan dan telah memenuhi spesifikasi yang dibutuhkan pengguna.

4. Hasil pengujian yang melibatkan lima buah smartphone Android yang memiliki spesifikasi berbeda-beda seperti versi Android yang digunakan, ukuran layar yang digunakan, dan juga brand dari kelima smartphone tersebut dapat diambil kesimpulan bahwa tampilan Aplikasi Pendataan dan Monitoring Reklame ini berbeda-beda pada tiap smartphone, perbedaan tampilan terdapat pada tingkat kecerahan warna. Kemudian perbedaan 
performa aplikasi ini juga ditemukan pada jenis smartphone dengan versi Android yang sudah cukup berumur seperti versi 4.4.4 (KitKat) dan versi 5.1 (Lollipop).

\section{DAFTAR PUSTAKA}

[1] Muhaimin, F. Adzim, and Firmansyah, "Analisis Potensi Pajak Reklame Terhadap Pendapatan," AMNESTY J. Ris. Perpajak., vol. 2, no. 2, pp. 53-58, 2019.

[2] N. Astika, "Pengawasan Pemasangan Papan Reklame di Kecamatan Tampan Kota Pekanbaru," vol. 5, no. July, pp. 123, 2016.

[3] A. Annugerah, I. F. Astuti, and A. H. Kridalaksana, "Sistem Informasi Geografis Berbasis Web Pemetaan Lokasi Toko Oleh-Oleh Khas Samarinda," Inform. Mulawarman J. Ilm. Ilmu Komput., vol. 11, no. 2, pp. 43-47, 2016, doi: 10.30872/jim.v11i2.213.

[4] I. Setiawan, "Peran Sistem Informasi Geografis (Sig) Dalam Meningkatkan Kemampuan Berpikir Spasial (Spatial Thinking)," J. Geogr. Gea, vol. 15, no. 1, pp. 83-89, 2016, doi: 10.17509/gea.v15i1.4187.

[5] Kholil, "Pemanfaatan Sistem Informasi Geografis (Sig) Dalam Aplikasi Pelaporan Dan Pelacakan Kejahatan Berbasis Android," J. Teknol. Inf. Dan Komun., vol. 6, no. 1, pp. 51-58, 2017.

[6] E. Harseno and V. Igor R Tampubolon, "Aplikasi Sistem Informasi Geografis Dalam Pemetaan Batas Administrasi, Tanah, Geologi, PENGGUNAAN LAHAN, LERENG, DAERAH ISTIMEWA YOGYAKARTA DAN DAERAH ALIRAN SUNGAI DI JAWA TENGAH MENGGUNAKAN SOFTWARE ARCVIEW GIS," Majalah Ilmiah UKRIM Edisi I. p. 63, 2007, [Online]. Available: http://ejurnal.ukrimuniversity.ac.id/file/11201.pd f.

[7] Saefudin and D. Susandi, "Sistem Informasi Geografis Untuk Analisa Spasial Potensi Lembaga Pendidikan Keterampilan," JSiI (Jurnal Sist. Informasi), vol. 7, no. 2, pp. 123-131,
2020, doi: 10.30656/jsii.v7i2.2380.

[8] H. Putra, Surya and E. Afri, "InfoTekJar : Jurnal Nasional Informatika dan Teknologi Jaringan Penerapan Sistem Informasi Geografis Berbasis Web untuk Pengembangan Pariwisata pada Kabupaten Langkat,” vol. 5, no. 1, p. '70174, 2020, [Online]. Available: https://doi.org/10.30743/infotekjar.v5i1.2 891.

[9] F. Masykur, "Implementasi Sistem Informasi Geografis Menggunakan Google Maps Api Dalam Pemetaan Asal Mahasiswa," J. SIMETRIS, vol. 5, no. 2, pp. 181-186, 2014.

[10] J. A. D. Pujayanti, B. Susilo, and D. Puspitaningrum, "Sistem Informasi Geografis Untuk Analisis Persebaran Pelayanan Kesehatan di Kota Bengkulu," J. Rekursif, vol. 2, no. 2, pp. 99-111, 2014, [Online]. Available: http://download.portalgaruda.org/article.p hp? article $=299334 \&$ val $=7008 \&$ title $=$ Sist em Informasi Geografis Untuk Analisis Persebaran Pelayanan Kesehatan di Kota Bengkulu. 